Bull. Chem. Soc. Ethiop. 2020, 34(2), 237-248.

ISSN 1011-3924

(C) 2020 Chemical Society of Ethiopia and The Authors

Printed in Ethiopia

DOI: https://dx.doi.org/10.4314/bcse.v34i2.3

\title{
OPTIMIZATION OF ULTRASOUND-ASSISTED EXTRACTION OF BIOACTIVE COMPOUNDS FROM GOMPHRENA CELOSIOIDES MART. USING RESPONSE SURFACE METHODOLOGY
}

\author{
Nguyen Thi Hoang Yen and Le Pham Tan Quoc* \\ Institute of Biotechnology and Food Technology, Industrial University of Ho Chi Minh City, Ho \\ Chi Minh City, Vietnam
}

(Received March 16, 2020; Revised September 23, 2020; Accepted September 28, 2020)

\begin{abstract}
In this study, ultrasound-assisted extraction (UAE) was used to extract bioactive compounds from Gomphrena celosioides Mart. Central composite face design (CCF) was used to optimize the influences of extraction factors on total phenolics content (TPC), total flavonoids content (TFC), and 1,1-diphenyl-2picrylhydrazyl free radical scavenging capacity (DPPH-RSC). The results obtained showed that all factors (solvent to solid ratio, extraction time and extraction temperature) strongly affected TPC, TFC, and DPPH-RSC. The optimal extraction conditions for TPC (3.123 mg GAE/g DW), TFC (1.736 mg QE/g DW), and DPPH-RSC $(64.118 \%)$ were solvent to solid ratio of $27.3 / 1(\mathrm{~mL} / \mathrm{g})$, extraction time of $40.2 \mathrm{~min}$, and extraction temperature of $69{ }^{\circ} \mathrm{C}$. In addition, under the optimal conditions, the results pointed out that the experimental values agreed with those predicted. Hence, this model has successfully optimized the extraction conditions for TPC, TFC and DPPHRSC of Gomphrena celosioides extract.
\end{abstract}

KEY WORDS: Antioxidant activity, CCF, Flavonoids, Model, Phenolic compounds, Regression equation

\section{INTRODUCTION}

During recent decades, the herbal plants were widely used in the pharmaceutical industry and the use of herbal medicines has provided a good opportunity for Vietnam to develop therapeutic compounds from an ancient system of therapy. According to the study of Pendse [1], natural product origin can produce over $50 \%$ of all modern drugs and the phytoconstituents of the herbal plant have an indispensable role in the pharmaceutical and medical industry. Plants contain a large number of bioactive constituents with diverse pharmacological properties and medicinal values. From those, they can manufacture many novel drugs with the high therapeutic value. One of herbal plant is Gomphrena celosioides Mart. (Common name: Bachelor's button or Prostrate globe-amaranth) that belongs to family Amaranthaceae, and originates from America, especially South America (Brazil, Paraguay, Uruguay, and Argentina). Then, this plant has spread throughout the tropical regions in the world [2] and it can be harvested all year round in Vietnam. All parts of this plant are useful, and they can cure many diseases such as antimicrobial, anticancer, antimalarial, analgesic, diarrhea, gastric disturbances, piles, and dermatitis [3].

Currently, many previous studies proved that G. celosioides plant contains many bioactive compounds, for instance, phenolic compounds and flavonoids were determined in leaves, inflorescence and stem [4-5], while betacyanins were found in the stem, reducing sugars were in the inflorescence, and ketoses were in the root and stem [6]. These compounds are quite precious for human, especially phenolic compounds. The scientists have been interested in these compounds which are widely distributed in the plant and are the most abundant secondary metabolites of plants [7]. They are antioxidant and anti-microorganism compounds and can be applied in the food industry as well as pharmaceutical manufacturing.

*Corresponding author. E-mail: lephamtanquoc@iuh.edu.vn

This work is licensed under the Creative Commons Attribution 4.0 International License 
Extraction is the first important stage in the recovery of bioactive compounds from initial materials. In fact, many extraction methods can be applied to extract bioactive compounds, including polyphenols, for instance, maceration, Soxhlet, microwave-assisted extraction, pressurized fluid extraction, supercritical fluid extraction, subcritical water extraction and accelerated solvent extraction [7]. However, the application of ultrasonic-assisted extraction (UAE) in food technology has widely attracted attentions because it has some advantages such as enhancement of yield, shortening of extraction time [8-9], simple apparatus, and low cost. In addition, UAE can be used both on a small scale in the laboratory and large scale in the extraction industry [10].

Until now, none of the studies mentioned UAE of bioactive compounds from aerial part of G. celosioides. TPC, TFC, and DPPH-RSC of extract strongly depend on extraction parameters such as solid to solvent ratio, extraction time and extraction temperature. Response surface methodology (RSM) was designed to optimize the bioactive compounds extraction process. In this study, the extraction conditions were used by central composite face (CCF) design. The results obtained from this model could provide important data for further researches.

\section{EXPERIMENTAL}

\section{Chemicals and reagents}

Gallic acid, Folin-Ciocalteu (FC), 1,1-diphenyl-2-picrylhydrazyl (DPPH), quercetin reagent were purchased from Sigma-Aldrich (USA). All organic solvents (ethanol and distilled water) and other chemicals $\left(\mathrm{Na}_{2} \mathrm{CO}_{3}, \mathrm{NaOH}, \mathrm{NaNO}_{2}\right.$, and $\left.\mathrm{AlCl}_{3}\right)$ used in this study were of analytical reagent grade.

\section{Sample preparation}

Fresh G. celosioides were harvested in $\mathrm{Cu}$ Chi district, Ho Chi Minh City (Vietnam) and stored at $0-4{ }^{\circ} \mathrm{C}$. Yellow leaves and broken branches were removed. Then, the remainder of this plant were washed, drained and dried at $60{ }^{\circ} \mathrm{C}$ to reduce the moisture content to less than $10 \%$. Dried samples were ground into small pieces in Philips (model HR2061, Malaysia) for $5 \mathrm{~min}$. The sample obtained (with particle size of $4 \mathrm{~mm}$ ) was then put into polyethylene bags, sealed and stored at $4{ }^{\circ} \mathrm{C}$. These samples were used for subsequent experiments.

\section{Extraction process}

Dried plant samples ( $2 \mathrm{~g})$ were extracted by ethanol as a solvent $(70 \%, \mathrm{v} / \mathrm{v})$, using a solvent to solid ratio of $20-30 \mathrm{~mL} / \mathrm{g}$, extraction time of $35-45 \mathrm{~min}$ and a temperature of $65-75{ }^{\circ} \mathrm{C}$. The extraction process was carried out using an ultrasonic bath (Elmasonic S60 H, $550 \mathrm{~W}$, Germany). All these extraction conditions based on our preliminary experiments and the values of operating parameters were set according to the CCF table (Table 1). The obtained extracts were filtered through Whatman filter paper (No. 4) under vacuum for removal of the residue. Finally, the extracts were analyzed to determine the amount of TPC, TFC, and DPPH-RSC.

Table 1. Coded level and actual values of independent factors of central composite face (CCF) design.

\begin{tabular}{|l|c|c|c|c|}
\hline \multirow{2}{*}{ Independent factors } & \multirow{2}{*}{ Symbols } & \multicolumn{3}{|c|}{ Coded levels } \\
\cline { 3 - 5 } & & -1 & 0 & 1 \\
\hline Solvent to material ratio $(\mathrm{mL} / \mathrm{g})$ & $\mathrm{X}_{1}$ & $20 / 1$ & $25 / 1$ & $30 / 1$ \\
\hline Extraction time $(\mathrm{min})$ & $\mathrm{X}_{2}$ & 35 & 40 & 45 \\
\hline Extraction temperature $\left({ }^{\circ} \mathrm{C}\right)$ & $\mathrm{X}_{3}$ & 65 & 70 & 75 \\
\hline
\end{tabular}

Bull. Chem. Soc. Ethiop. 2020, 34(2) 
Determination of total phenolics content (TPC)

TPC of G. celosioides extract was determined by Folin-Ciocalteu colorimetric assay according to the study of Siddiqua et al. [11]. The crude extract was made up to $100 \mathrm{~mL}$ of the same extraction solvent. Approximately $3 \mathrm{~mL}$ of the diluted extract was added $1 \mathrm{~mL}$ of FolinCiocalteu reagent and was remained unchanged at room temperature for $5 \mathrm{~min}$, then, $3 \mathrm{~mL}$ of sodium carbonate $(20 \%, \mathrm{w} / \mathrm{v})$ and $3 \mathrm{~mL}$ of aqueous ethanol $70 \%(\mathrm{v} / \mathrm{v})$ were added. After that, the mixture obtained was kept in dark for 30 min and absorbance was measured at $738 \mathrm{~nm}$ using a spectrophotometer (Genesys 20, USA). Measurements were based on a calibration curve obtained with gallic acid as a standard reagent. TPC was expressed as $\mathrm{mg}$ of gallic acid equivalents (GAE) per gram of dry weight (DW).

Determination of total flavonoids content (TFC)

TFC of G. celosioides extract was determined according to the method of Kamtekar et al. [12] with some modifications. Plant extract obtained was made up to $100 \mathrm{~mL}$ of aqueous ethanol $70 \%(\mathrm{v} / \mathrm{v})$. Then, the extract $(1 \mathrm{~mL})$ was added $0.3 \mathrm{~mL}$ of $5 \%$ sodium nitrite solution $(\mathrm{w} / \mathrm{v}), 0.3$ $\mathrm{mL}$ of $10 \%$ aluminum chloride $(\mathrm{w} / \mathrm{v})$, and was shaken for $5 \mathrm{~min}$. After that, this solution was added $2 \mathrm{~mL}$ sodium hydroxide (1 M), and was stayed unchanged for $6 \mathrm{~min}$. Lastly, the mixture was made up to $5 \mathrm{~mL}$ with ethanol solution $(95 \%, \mathrm{v} / \mathrm{v})$ and mixed well. The absorbance was measured at $510 \mathrm{~nm}$. TFC was estimated from a standard curve obtained with quercetin and final results were expressed as mg of quercetin equivalents $(\mathrm{QE})$ per gram of dry weight (DW).

Determination of DPPH free radical scavenging capacity (DPPH-RSC)

The free radical scavenging capacity of $G$. celosioides extract was determined following the assay suggested by Ramadan et al. [13] with some slight changes. Firstly, the extract $(0.8 \mathrm{~mL})$ was mixed with $4 \mathrm{~mL}$ of ethanolic solution of DPPH $(0.1 \mathrm{mM})$ and filled up to $5 \mathrm{~mL}$ with ethanol solution. The mixture was kept for $30 \mathrm{~min}$ in dark at room temperature, then the absorbance was measured at $517 \mathrm{~nm}$ and expressed as DPPH-RSC. DPPH-RSC was calculated based on the following equation:

DPPH-RSC $(\%)=\left(\mathrm{A}_{0}-\mathrm{A}\right) \times 100 / \mathrm{A}_{0} ;$ where $\mathrm{A}_{0}$ and A were the absorbance of the control (without the plant extract) and sample solution, respectively.

\section{Experimental design}

RSM with a three-factor (solvent to solid ratio, extraction time and temperature) and rotatable central composite face design (CCF) consisting of 17 experimental runs were applied to optimize extraction conditions for extraction of bioactive compounds in G. celosioides. All levels of independent variables and CCF design are presented in Table 1-2, respectively.

Second-order polynomial equations were used to express the investigated responses (Y), namely total polyphenol content $\left(\mathrm{Y}_{1}, \mathrm{mg}\right.$ GAE/g DW), total flavonoid content $\left(\mathrm{Y}_{2}, \mathrm{mg} \mathrm{QE} / \mathrm{g}\right.$ $\mathrm{DW})$, and DPPH free radical scavenging capacity $\left(\mathrm{Y}_{3}, \%\right)$ of G. celosioides extract as a function of the coded independent variables, where $\mathrm{X}_{1}, \mathrm{X}_{2}, \mathrm{X}_{3}$ were the independent variables affecting the responses. Basically, a second order polynomial model used in the response surface analysis with 3 variables was as follows:

$Y_{i}=a_{o}+a_{1} X_{1}+a_{2} X_{2}+a_{3} X_{3}+a_{11} X_{1}^{2}+a_{22} X_{2}^{2}+a_{33} X_{3}^{2}+a_{12} X_{1} X_{2}+a_{13} X_{1} X_{3}+a_{23} X_{2} X_{3}$

This equation also showed the relationship between independent variables and investigated responses $\left(\mathrm{Y}_{\mathrm{i}}\right)$. 
Table 2. Experimental design matrix, experimental values (EV) and predicted values (PV) for TPC, TFC, and DPPH-RSC.

\begin{tabular}{|c|c|c|c|c|c|c|c|c|c|}
\hline \multirow{2}{*}{ Run } & \multicolumn{1}{|c|}{ Independent factors of the extraction } & \multicolumn{9}{|c|}{ Responses } \\
\cline { 2 - 10 } & \multirow{2}{*}{$\mathrm{X}_{1}$} & $\mathrm{X}_{2}$ & \multirow{2}{*}{$\mathrm{X}_{3}$} & \multicolumn{2}{|c|}{$\mathrm{Y}_{1}$} & \multicolumn{2}{|c|}{$\mathrm{Y}_{2}$} & \multicolumn{2}{|c|}{$\mathrm{Y}_{3}$} \\
\cline { 5 - 10 } & & & $\mathrm{EV}$ & $\mathrm{PV}$ & $\mathrm{EV}$ & $\mathrm{PV}$ & $\mathrm{EV}$ & $\mathrm{PV}$ \\
\hline 1 & 20 & 35 & 65 & 2.634 & 2.609 & 1.491 & 1.489 & 57.180 & 57.720 \\
\hline 2 & 30 & 35 & 65 & 2.76 & 2.758 & 1.669 & 1.676 & 61.910 & 61.321 \\
\hline 3 & 20 & 45 & 65 & 2.801 & 2.816 & 1.593 & 1.604 & 55.970 & 55.649 \\
\hline 4 & 30 & 45 & 65 & 2.95 & 2.947 & 1.694 & 1.679 & 57.650 & 58.034 \\
\hline 5 & 20 & 35 & 75 & 2.691 & 2.680 & 1.519 & 1.536 & 51.480 & 51.177 \\
\hline 6 & 30 & 35 & 75 & 2.911 & 2.882 & 1.573 & 1.563 & 54.320 & 54.722 \\
\hline 7 & 20 & 45 & 75 & 2.683 & 2.671 & 1.662 & 1.657 & 51.210 & 51.880 \\
\hline 8 & 30 & 45 & 75 & 2.844 & 2.855 & 1.569 & 1.572 & 54.670 & 54.211 \\
\hline 9 & 20 & 40 & 70 & 2.898 & 2.931 & 1.684 & 1.662 & 61.038 & 60.453 \\
\hline 10 & 30 & 40 & 70 & 3.076 & 3.098 & 1.697 & 1.713 & 63.156 & 63.418 \\
\hline 11 & 25 & 35 & 70 & 2.885 & 2.951 & 1.651 & 1.639 & 63.092 & 63.043 \\
\hline 12 & 25 & 45 & 70 & 3.051 & 3.041 & 1.695 & 1.701 & 62.025 & 61.751 \\
\hline 13 & 25 & 40 & 65 & 2.97 & 2.985 & 1.707 & 1.706 & 60.902 & 60.889 \\
\hline 14 & 25 & 40 & 75 & 2.934 & 2.975 & 1.680 & 1.676 & 56.015 & 55.705 \\
\hline 15 & 25 & 40 & 70 & 3.157 & 3.107 & 1.724 & 1.726 & 64.101 & 63.520 \\
\hline 16 & 25 & 40 & 70 & 3.143 & 3.107 & 1.717 & 1.726 & 63.250 & 63.520 \\
\hline 17 & 25 & 40 & 70 & 3.131 & 3.107 & 1.726 & 1.726 & 62.563 & 63.520 \\
\hline
\end{tabular}

Statistical data analysis

All analyses were performed in triplicate. All the experimental data collected from the extraction process were analyzed by using software Modde 5.0 (Umetrics AB company, Sweden) that was set to search the optimum desirability of the investigated response, for instance, the maximal TPC, TFC, and DPPH-RSC. Strength of analysis was assessed by oneway analysis of variance (ANOVA). The optimal extraction conditions were determined by three-dimensional (3D) response surfaces and contour plots.

\section{RESULTS AND DISCUSSION}

\section{Effect of different UAE factors on responses (TPC, TFC, and DPPH-RSC)}

Some factors of the ultrasonic-assisted extraction (UAE) on phenolics, flavonoids and antioxidant ability of compounds extracted from the dried $G$. Celosioides were addressed by the preliminary surveys. After that, major terms including solvent to material ratio, temperature and time extraction were implemented to optimize of the extraction conditions.

Table 3 illustrates that the multivariable linear regression was considered to analyze and calculate the constants, coefficients of linear, quadratic and interaction effects of extraction factors. The polynomial equations (2, 3 and 4$)$ were gained (after removing all non-significant factors) and shown the following forms:

$$
\begin{aligned}
& \mathrm{Y}_{1}=3.107+0.083 \mathrm{X}_{1}+0.045 \mathrm{X}_{2}-0.092 \mathrm{X}_{1}^{2}-0.111 \mathrm{X}_{2}^{2}-0.127 \mathrm{X}_{3}^{2}-0.054 \mathrm{X}_{2} \mathrm{X}_{3} \\
& \mathrm{Y}_{2}=1.726+0.025 \mathrm{X}_{1}+0.031 \mathrm{X}_{2}-0.015 \mathrm{X}_{3}-0.038 \mathrm{X}_{1}^{2}-0.056 \mathrm{X}_{2}^{2}-0.035 \mathrm{X}_{3}^{2}- \\
& 0.028 \mathrm{X}_{1} \mathrm{X}_{2}-0.04 \mathrm{X}_{1} \mathrm{X}_{3}
\end{aligned}
$$


Ultrasound-assisted extraction of bioactive compounds from Gomphrena celosioides Mart. 241

$\mathrm{Y}_{3}=63.52+1.483 \mathrm{X}_{1}-0.646 \mathrm{X}_{2}-2.592 \mathrm{X}_{3}-1.585 \mathrm{X}_{1}^{2}-1.123 \mathrm{X}_{2}^{2}-5.223 \mathrm{X}_{3}^{2}+0.694 \mathrm{X}_{2} \mathrm{X}_{3}$

where $\mathrm{Y}_{1}, \mathrm{Y}_{2}, \mathrm{Y}_{3}$ were TPC (mg GAE/g DW), TFC (mg QE/g DW), and DPPH-RSC (\%), respectively.

Table 3. Analysis of variance and regression equation coefficients of the models for TPC, TFC, and DPPHRSC.

\begin{tabular}{|c|c|c|c|c|c|c|}
\hline \multirow[t]{2}{*}{ Factors } & \multicolumn{2}{|c|}{$\mathrm{Y}_{1}$} & \multicolumn{2}{|c|}{$\mathrm{Y}_{2}$} & \multicolumn{2}{|c|}{$\mathrm{Y}_{3}$} \\
\hline & Coefficient & $\mathrm{p}_{\text {value }}$ & Coefficient & $\mathrm{p}_{\text {value }}$ & Coefficient & $\mathrm{p}_{\text {value }}$ \\
\hline Constant & 3.107 & 0.000 & 1.726 & 0.000 & 63.520 & 0.000 \\
\hline $\mathrm{X}_{1}$ & 0.083 & 0.001 & 0.025 & 0.002 & 1.483 & 0.000 \\
\hline $\mathrm{X}_{2}$ & 0.045 & 0.017 & 0.031 & 0.001 & -0.646 & 0.026 \\
\hline $\mathrm{X}_{3}$ & -0.005 & 0.728 & -0.015 & 0.021 & -2.592 & 0.000 \\
\hline $\mathrm{X}_{1}^{2}$ & -0.092 & 0.013 & -0.038 & 0.006 & -1.585 & 0.009 \\
\hline $\mathrm{X}_{2}{ }^{2}$ & -0.111 & 0.005 & -0.056 & 0.001 & -1.123 & 0.040 \\
\hline $\mathrm{X}_{3}{ }^{2}$ & -0.127 & 0.003 & -0.035 & 0.009 & -5.223 & 0.000 \\
\hline $\mathrm{X}_{1} \mathrm{X}_{2}$ & -0.005 & 0.788 & -0.028 & 0.002 & -0.304 & 0.277 \\
\hline $\mathrm{X}_{1} \mathrm{X}_{3}$ & 0.013 & 0.437 & -0.040 & 0.000 & -0.014 & 0.959 \\
\hline $\mathrm{X}_{2} \mathrm{X}_{3}$ & -0.054 & 0.012 & 0.002 & 0.801 & 0.694 & 0.031 \\
\hline $\mathrm{Q}^{2}$ & \multicolumn{2}{|c|}{0.793} & \multicolumn{2}{|c|}{0.722} & \multicolumn{2}{|c|}{0.841} \\
\hline $\mathrm{R}^{2}$ & \multicolumn{2}{|c|}{0.967} & \multicolumn{2}{|c|}{0.979} & \multicolumn{2}{|c|}{0.987} \\
\hline $\mathrm{R}_{\mathrm{adj}}{ }^{2}$ & \multicolumn{2}{|c|}{0.923} & \multicolumn{2}{|c|}{0.951} & \multicolumn{2}{|c|}{0.971} \\
\hline $\mathrm{p}_{\text {value }}$ & \multicolumn{2}{|c|}{0.000} & \multicolumn{2}{|c|}{0.000} & \multicolumn{2}{|c|}{0.000} \\
\hline Lack of Fit $(\mathrm{F})$ & \multicolumn{2}{|c|}{0.057} & \multicolumn{2}{|c|}{0.060} & \multicolumn{2}{|c|}{0.618} \\
\hline
\end{tabular}

In addition, Table 3 also shows that the $\mathrm{p}_{\text {value }}$ of all models were $0.000(<0.05)$. These results meant that these models were significant. Furthermore, the lack of fits of the models for TPC, TFC, and DPPH-RSC were 0.057, 0.06 and $0.618(>0.05)$, respectively. Hence, the consequences were not significant for them. Those also pointed out that the models were the good predictability of the responses. On the other hand, all coefficients of determinations were higher than 0.9 ( $\mathrm{R}^{2}$ from 0.967 to 0.987 ). So, more than $96.7 \%$ of the actual data in the responses; while all adjusted coefficients of determinations ( $\mathrm{R}_{\text {adj }}^{2}$ among $92.3-97.1 \%$ ) were quite close to the above-mentioned $\mathrm{R}^{2}$ values, demonstrating that the actual and forecasting data had high fitting precisions, proving the feasibility of the experimental method. Moreover, $\mathrm{Q}^{2}$ parameters in the models were the goodness of anticipations and estimations of these models. $\mathrm{Q}^{2}$ values for TPC, TFC, and DPPH-RSC in this study were $0.793,0.722$, and 0.841 , respectively. Therefore, these results should be asserted as good $\left(\mathrm{Q}^{2}>0.5\right.$ and $\left.\mathrm{R}^{2}-\mathrm{Q}^{2}<0.3\right)$ according to the proposal of Eriksson et al. [14]. For these reasons, the models were quite apparent evidences for the predicting responses.

Based on the afore-mentioned equations, TPC, TFC, and DPPH-RSC depended on all variables of the extraction process such as solvent to material ratio, extraction temperature and extraction time. Besides, TPC was impacted significantly by the quadratic effects of time and temperature extraction in comparison with the remaining factor. Moreover, among the analyzed factors, the process temperature became the greatest influence on the final DPPH-RSC, compared with solvent to material ratio and extraction time factors. Meanwhile, TFC was influenced quite similar by all experimental factors. Additionally, extraction temperature was a negative impact on all responses. These meant that the extracted temperature rose, the amount of TPC, TFC, and DPPH-RSC of the extract would decrease. When it comes to the interactions between factors, there were the interactions between extraction time and temperature on both TPC and DPPH-RSC responses, while TFC response was affected by both the interactions including between solvent to material ratio and extraction time, between solvent to material ratio and extraction temperature. These results were quite resembled the study of He et al. [15], who 
referred that there were the interactions between extraction time and temperature, solvent to solid ratio and extraction time, solvent to solid ratio and extraction temperature in ultrasoundassisted extraction of phenolic compounds and anthocyanins from blueberry (Vaccinium ashei).

\section{Response surface plots}

Table 2 shows that the amount of TPC, TFC, and DPPH-RSC of dried G. celosioides extracts allocated from 2.634 to $3.157 \mathrm{mg} \mathrm{GAE} / \mathrm{g}$ DW, between 1.491 and $1.726 \mathrm{mg}$ QE/g DW and from 51.210 to $64.101(\%)$, respectively. The three-dimensional response surfaces of the models and contour plots were applied to determine the influences and interactions of experimental factors by $3 \mathrm{D}$ response surface curves (Figures 1-3). The correlation between responses and factors was depicted in the response surface plot. Each plot provided how two factors altered and impacted, while the third one was remained unchanged.

Besides, regarding contour plot of interaction between time and temperature extraction at the fixed ratio of 25/1 (mL/g), shown in Figures 1-3, the increase of the extraction time from 35 to $38.4 \mathrm{~min}$ as well as the growth of temperature extraction between 65 and $69{ }^{\circ} \mathrm{C}$ led to the enhancements of the extraction yield of TPC (from 2.809 to $3.081 \mathrm{mg} \mathrm{GAE} / \mathrm{g} \mathrm{DW}$ ), TFC (from 1.588 to $1.714 \mathrm{mg} \mathrm{QE} / \mathrm{g} \mathrm{DW}$ ), and DPPH-RSC (from 61.180 to $63.080 \%$ ).

Higher temperature can lead to remarkable improvements in efficiency of the extraction processes of bioactive compounds. This is due to the fact that increasing temperature encourages to disrupt the bonds in plant cell walls as well as to break off the phenolic matrix bonds, leading to dissolving capacity of bioactive compounds also rises [16]. Moreover, the viscosity of solvents declines while solubility and diffusion into the solvents of bioactive compounds increase at the higher temperature [17]. In addition, bioactive substances such as polyphenol, flavonoid, vitamin, etc. show antioxidant characteristic. Therefore, the higher extraction temperature was the higher yield of TPC, TFC, and DPPH-RSC in the extracts obtained.

Extraction time and solvent to material ratio are also two in the main factors which affect noticeably on extraction procedure. That is basically because extraction time relates to energy cost as well as inhibiting the decomposition of active compounds. Extraction time usually depends on the type of materials and extraction process. Besides, structure materials will absorb the solvent and swell, so the amount of solvent must be sufficient to immerse whole materials [18]. Furthermore, the solvents will be serviced to dissolve the extracts in materials. Thus, according to Figures $1-3$, as the solvent to material ratio increased from $22 / 1$ to $24.5 / 1(\mathrm{~mL} / \mathrm{g})$ along with extraction time rose from 37 to $40 \mathrm{~min}$ at the constant temperature of $70{ }^{\circ} \mathrm{C}$, the amount of TPC, TFC, and DPPH-RSC also increased from 2.951 to $3.095 \mathrm{mg}$ GAE/g DW, from 1.638 to $1.710 \mathrm{mg} \mathrm{QE} / \mathrm{g} \mathrm{DW}$, and between 61.490 and $63.490 \%$, respectively.

However, these responses decreased with longer extraction time or higher temperature or overwhelming solvents added. These results were explained that bioactive substances are degraded rapidly by thermal factor for a long time. Furthermore, these compounds are also oxidized quickly by the surrounding atmosphere. Besides, the substances that are not antioxidant capabilities, such as carbohydrates, minerals, etc. also increase during the extraction process [19].

\section{Determination and validation of optimal conditions}

According to the results of the RSM, the optimized extraction parameters from dried $G$. celosioides for the highest values of TPC, TFC, and DPPH-RSC approaches proposed that the optimal extraction conditions were extraction time of $40.179 \mathrm{~min}$, extraction temperature of $69.188{ }^{\circ} \mathrm{C}$ and ethanol to material ratio of $27.266 / 1(\mathrm{~mL} / \mathrm{g})$. However, considering operating convenience for the ultrasound system, optimal values of variables were determined including extraction time of $40.2 \mathrm{~min}$, temperature of $69^{\circ} \mathrm{C}$ and ethanol to material ratio of $27.3 / 1$. Under 
Ultrasound-assisted extraction of bioactive compounds from Gomphrena celosioides Mart. 243

the described above processing parameters, the optimum values (OV) of TPC, TFC, and DPPHRSC were anticipated to be $3.124 \mathrm{mg}$ GAE/g DW, $1.735 \mathrm{mg}$ QE/g DW, and $64.117 \%$, respectively (Table 4 ).

The validation of the UAE method was applied to check the suitability of the models. The experimental values (EV) under optimum conditions achieved that TPC, TFC, and DPPH-RSC were similar to the forecasted values. Thus, these extraction conditions were reasonable and the optimum process parameters were correctness.

Table 4. Results of optimal conditions.

\begin{tabular}{|c|c|c|c|c|c|c|c|c|}
\hline \multicolumn{4}{|c|}{ Factors } & \multicolumn{2}{c|}{$\mathrm{Y}_{1}(\mathrm{mg} \mathrm{GAE} / \mathrm{g} \mathrm{DW})$} & $\mathrm{Y}_{2}(\mathrm{mg} \mathrm{QE} / \mathrm{g} \mathrm{DW})$ & \multicolumn{2}{c|}{$\mathrm{Y}_{3}(\%)$} \\
\hline $\mathrm{X}_{1}(\mathrm{~mL} / \mathrm{g})$ & $\mathrm{X}_{2}(\mathrm{~min})$ & $\mathrm{X}_{3}\left({ }^{\circ} \mathrm{C}\right)$ & $\mathrm{OV}$ & $\mathrm{EV}$ & $\mathrm{OV}$ & $\mathrm{EV}$ & $\mathrm{OV}$ & $\mathrm{EV}$ \\
\hline 27.3 & 40.2 & 69 & 3.124 & $3.123 \pm 0.006$ & 1.735 & $1.736 \pm 0.005$ & 64.117 & $64.118 \pm 0.003$ \\
\hline
\end{tabular}

A

B

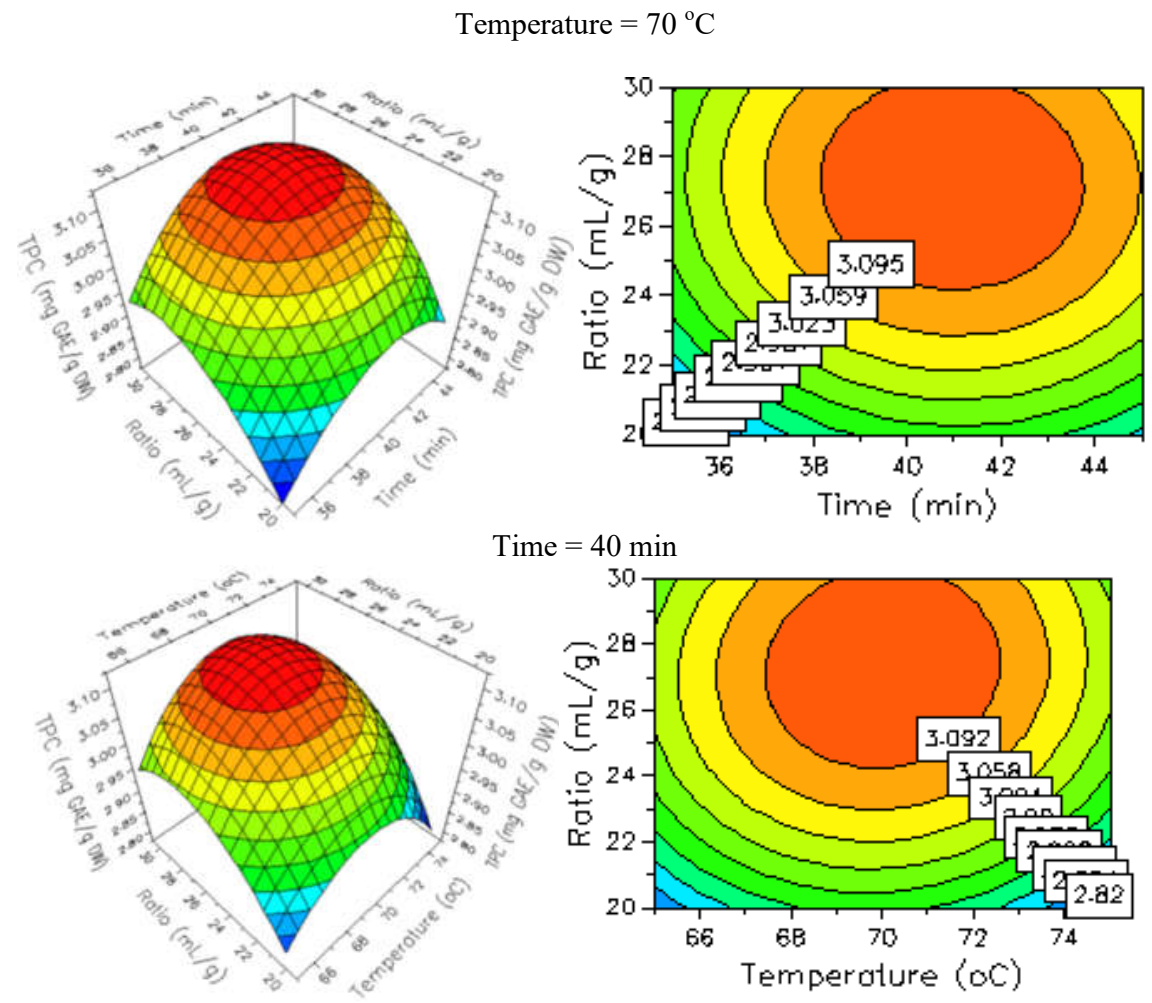

Bull. Chem. Soc. Ethiop. 2020, 34(2) 


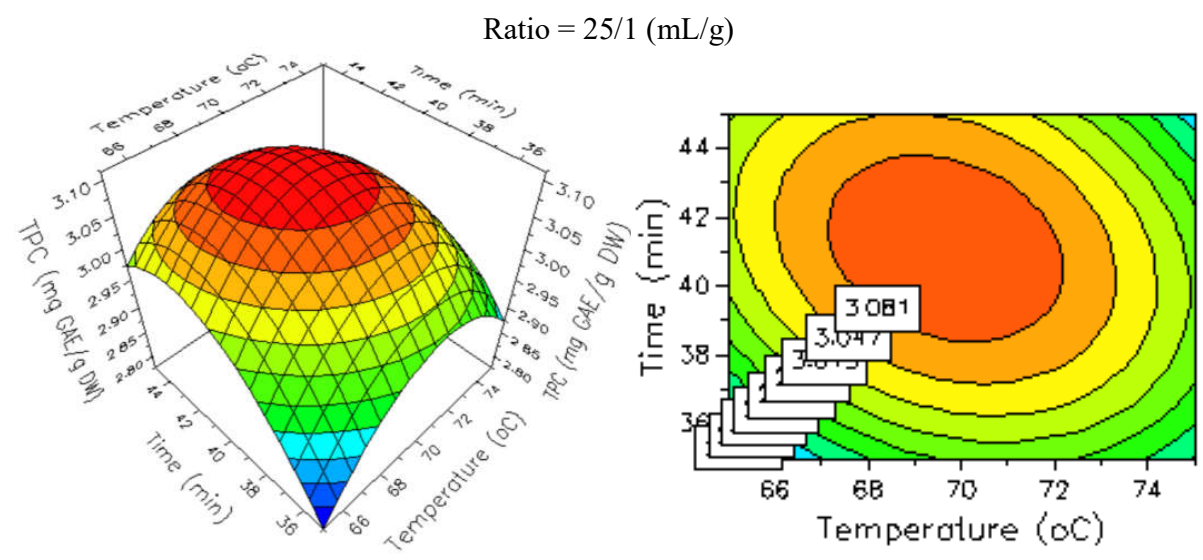

Figure 1. Response surfaces (A) and contour plots (B) for effecting of extraction process conditions on TPC from $G$. celosisoides extract at each center constant factor.

$\mathrm{C}$

$\mathrm{D}$

Temperature $=70{ }^{\circ} \mathrm{C}$
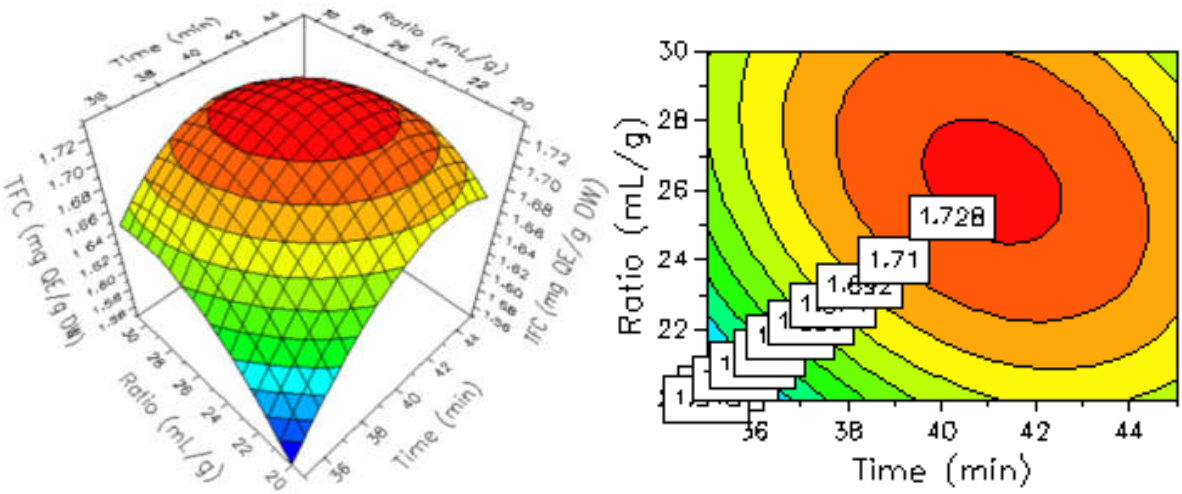

Bull. Chem. Soc. Ethiop. 2020, 34(2) 
Time $=40 \mathrm{~min}$
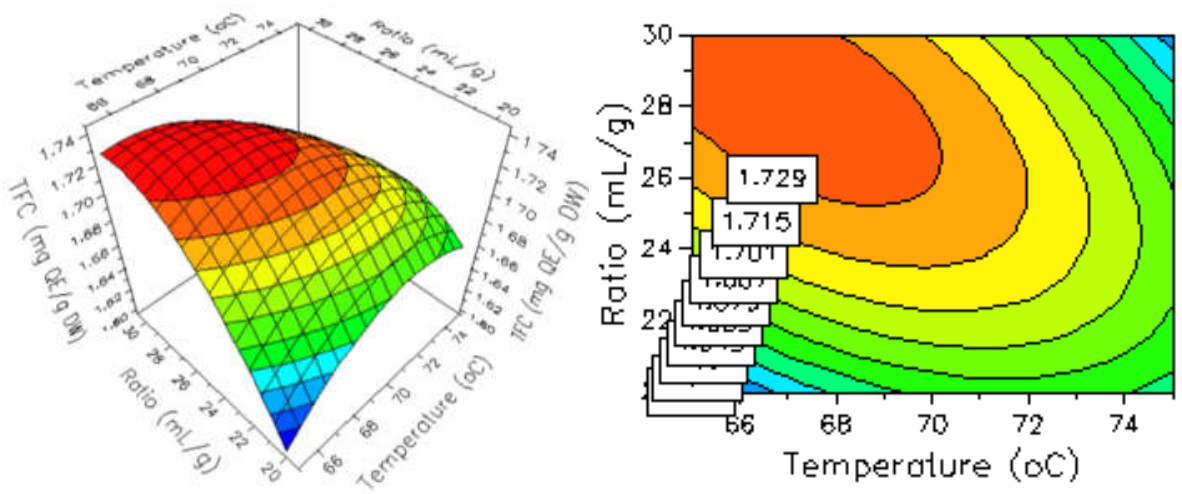

Ratio $=25 / 1(\mathrm{~mL} / \mathrm{g})$
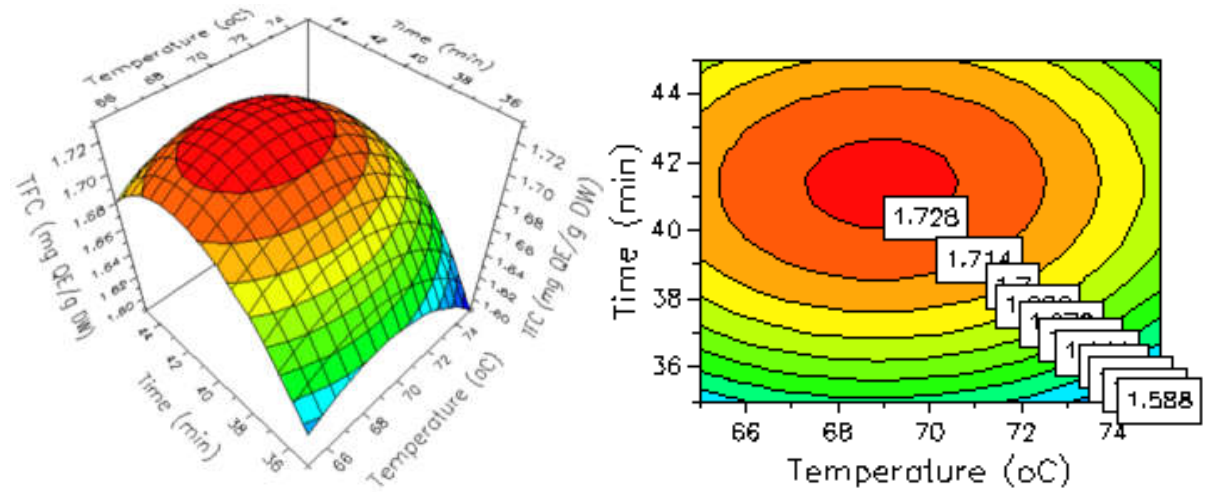

Figure 2. Response surfaces (C) and contour plots (D) for effecting of extraction process conditions on TFC from $G$. celosisoides extract at each center constant factor.

Optimum extraction parameters of this study were similar to study of He et al. [15], who extracted TPC with 16.03 (mg GAE/g) from blueberry (Vaccinium ashei) under the optimal conditions such as $61{ }^{\circ} \mathrm{C}$, liquid to solid ratio of $22(\mathrm{v} / \mathrm{w})$ and $24 \mathrm{~min}$ sonication time. However, these optimum factors in this study were different from that of Tomšik et al. [20], they used UAE to extract bioactive compounds from wild garlic (Allium ursinum L.) at $80{ }^{\circ} \mathrm{C}, 70 \%$ ethanol, $79.8 \mathrm{~min}$ (ultrasonic power of and $20.06 \mathrm{~W} / \mathrm{L}$ ) and achieved results including values of TPC (1.60 g GAE/100 g DW), TFC (0.35 g CE/100 g DW), antioxidant activity, $\mathrm{IC}_{50}(0.71$ $\mathrm{mg} / \mathrm{mL})$ and extraction yield, EY (38.1\%). These different results can be explained by the differences in plants species as well as the extraction methods. Furthermore, flavonoids compounds usually account for the highest percentage in phenolic groups from plants and phenolic substances often represent antioxidant abilities [17]. Therefore, the higher ratio of phenolic compounds the plants have the higher antioxidant capacity they refer. 
Temperature $=70{ }^{\circ} \mathrm{C}$

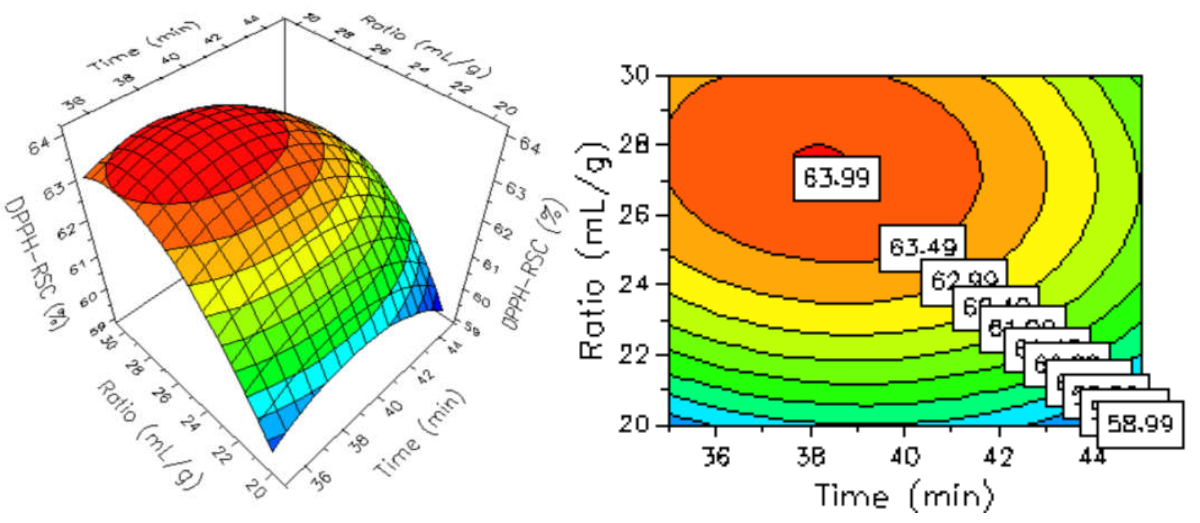

Time $=40 \mathrm{~min}$
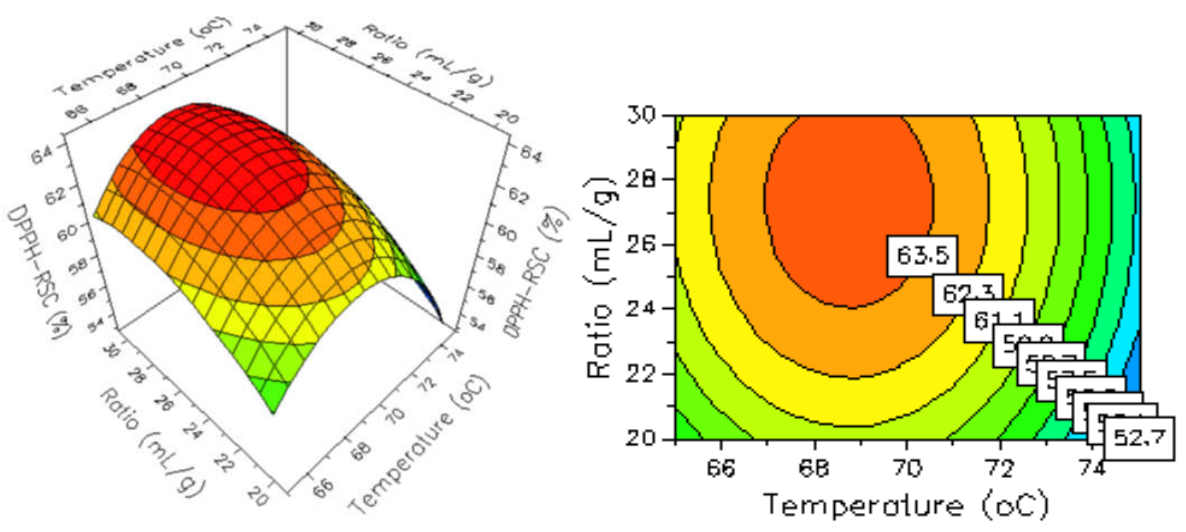

Bull. Chem. Soc. Ethiop. 2020, 34(2) 
Ratio $=25 / 1(\mathrm{~mL} / \mathrm{g})$
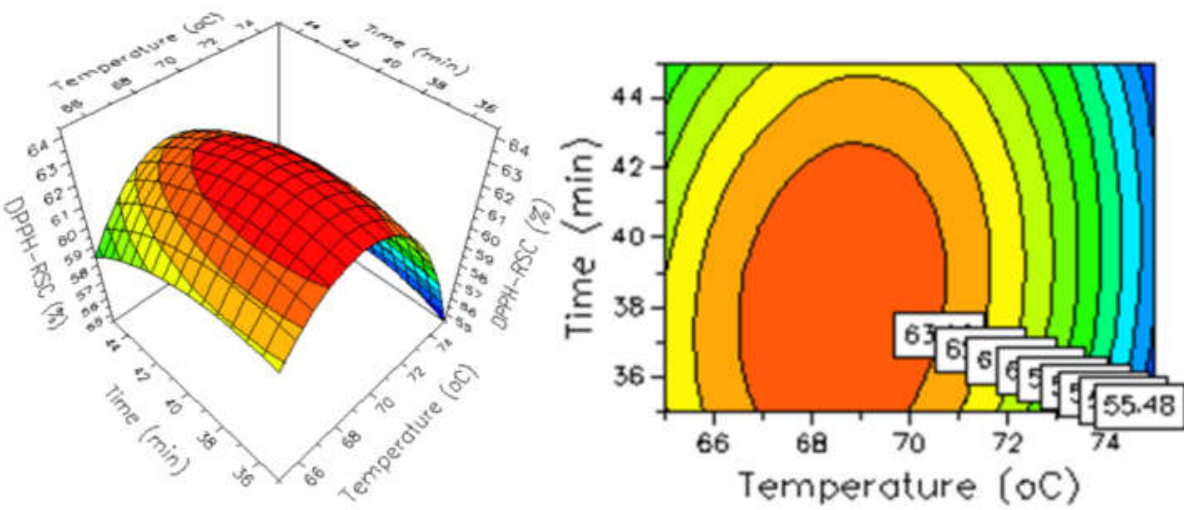

Figure 3. Response surfaces (E) and contour plots (F) for effecting of extraction process conditions on DPPH-RSC from G. celosisoides extract at each center constant factor.

\section{CONCLUSION}

In summary, the amount of TPC, TFC, and DPPH-RSC from dried G. celosioides obtained the highest extraction yield at the experimental optimum conditions through the application of RSM with CCF design. All factors of the extraction process affected significantly on the yields of TPC, TFC, and DPPH-RSC. The best combination of factors for maximum TPC, TFC, and DPPH-RSC was recorded to be ethanol to material ratio of $27.3 / 1(\mathrm{~mL} / \mathrm{g})$, extraction time of $40.2 \mathrm{~min}$ and extraction temperature of $69{ }^{\circ} \mathrm{C}$. Under optimal conditions, the experimental values were in total agreements with the predicted values and the mathematical model had a high correlation. These models would be useful for a large-scale extraction process of bioactive compounds from dried G. celosioides.

\section{REFERENCES}

1. Pendse, A.K. A comparative study on prevalence and urinary profile. Bull III, Ann. Conf. Urol. Soc. India; 1985; $\mathrm{p} 12$.

2. Dosumu, O.O.; Onocha, P.; Ekundayo, O.; Ali, M. Isolation of aurantiamides from Gomphrena celosioides C. Mart. Iran. J. Pharm. Res. 2014, 13, 143-147.

3. Nandini, K.N.; Palaksha, M.N.; Gnanasekaran, D. A review of Gomphrena serrata. Int. J. Sci. Res. Methodol. 2018, 11, 104-110.

4. Ilyas, M.; Tarnam, A.; Begum, N. Biological potential and phytopharmacological screening of Gomphrena species. Global J. Pharmacol. 2013, 7, 457-464.

5. Adeoti, M.F.; Gogahy, K.; Bidie, P.A.; Camara-Cesse, M.; Monteomo, F.G.; Kolia, I.K.; Djaman, J.A.; Dosso, M. Anti-inflammatory and antioxidant effects of ethanol extract of Gomphrena celosioides (Amaranthaceae) in wistar rats. J. Pharm., Chem. Biol. Sci. 2016, 4, 503-511.

6. Onocha, P.A.; Ajaiyeoba, E.O.; Dosumu, O.O.; Ekundayo, O. Phytochemical screening and biological activities of Gomphrena celosioides (C. Mart) extracts. J. Niger. Soc. Exp. Biol. 2005, 5, 61-67. 
7. Dai, J.; Mumper, R.J. Plant phenolics: Extraction, analysis and their antioxidant and anticancer properties. Mol. 2010, 15, 7313-7352.

8. Toma, M.; Vinatoru, M.; Paniwnyk, L.; Mason, T.J. Investigation of the effects of ultrasound on vegetal tissues during solvent extraction. Ultrason. Sonochem. 2001, 8, 137 142.

9. Wu, J.; Lin, L.; Chau, F. Ultrasound-assisted extraction of ginseng saponins from ginseng roots and cultured ginseng cells. Ultrason. Sonochem. 2001, 8, 347-352.

10. Vinatoru, M. An overview of the ultrasonically assisted extraction of bioactive principles from herbs. Ultrason. Sonochem. 2001, 8, 303-313.

11. Siddiqua, A.; Premakumari, K.B.; Sultana, R.; Vithya; Savitha. Antioxidant activity and estimation of total phenolic content of Muntingia calabura by colorimetry. Int. J. ChemTech Res. 2010, 2, 205-208.

12. Kamtekar, S.; Keer, V.; Patil, V. Estimation of phenolic content, flavonoid content, antioxidant and alpha amylase inhibitory activity of marketed polyherbal formulation. $J$. Appl. Pharm. Sci. 2014, 4, 61-65.

13. Ramadan, M.F.; Kroh, L.W.; Morsel, J.T. Radical scavenging activity of black cumin (Nigella sativa $\mathrm{L}$ ), coriander (Coriandrum sativum L), and niger (Guizotia abyssinica Cass.) crude seed oils and oil fractions. J. Agric. Food Chem. 2003, 51, 6961-6969.

14. Eriksson, L.; Johansson, E.; Kettaneh-Wold, N.; Wikstrom, C.; Wold, S. Design of Experiments: Principles and Applications, Umetrics Academy: Sweden; 2008; p 459.

15. He, B.; Zhang, L.L.; Yue, X.Y.; Liang, J.; Jiang, J.; Gao, X.L.; Yue, P.X. Optimization of ultrasound-assisted extraction of phenolic compounds and anthocyanins from blueberry (Vaccinium ashei) wine pomace. Food Chem. 2016, 204, 70-76.

16. Ghitescu, R.E.; Volf, I.; Carausu, C.; Bühlmann, A.M.; Gilca, I.A.; Popa, V.I. Optimization of ultrasound assisted extraction of polyphenols from spruce wood bark. Ultrason. Sonochem. 2015, 22, 535-541.

17. Arruda, H.S.; Pereira1, G.A.; Pastore, G.M. Optimization of extraction parameters of total phenolics from Annona crassiflora Mart. (Araticum) fruits using response surface methodology. Food Anal. Methods 2016, 10, 100-110.

18. Tao, Y.; Wu, D.; Zhang, Q.A.; Sun, D.W. Ultrasound-assisted extraction of phenolics from wine lees: modeling, optimization and stability of extracts during storage. Ultrason. Sonochem. 2014, 21, 706-715.

19. Piechowiak, T.; Grzelak-Błaszczyk, K.; Bonikowski, R.; Balawejder, M. Optimization of extraction process of antioxidant compounds from yellow onion skin and their use in functional bread production. LWT - Food Sci. Technol. 2020, 117, 1-7.

20. Tomšik, A.; Pavlic, B.; Vladic, J.; Ramic, M.; Brindza, J.; Vidovic, S. Optimization of ultrasound-assisted extraction of bioactive compounds from wild garlic (Allium ursinum L.). Ultrason. Sonochem. 2016, 29, 502-511. 